\title{
Learning Similarity Lawang Sewu using Context for Third Grade Lower Secondary School Students
}

\author{
Achmad Fahrurozi $^{1}$, Suci Maesaroh ${ }^{2}$, Imam Suwanto $^{3}$, Farida Nursyahidah ${ }^{4}$ \\ 1,2,3,4 Faculty of Mathematics and Natural Science Education and Information Technology, University of PGRI \\ Semarang, 50125, Indonesia \\ ${ }^{4}$ Corresponding author e-mail: faridanursyahidah@upgris.ac.id
}

\begin{abstract}
This study aims to produce a learning trajectory by using the context of Lawang Sewu in helping students to understand the concept of similarity. The approach used in this research was Realistic Mathematics Education, in Indonesian version is called by PMRI. Subject of the study is the third-grade students of SMP 37 Semarang, Central Java, Indonesia, involving 6 students who were chosen in heterogeneous capabilities. The methodology used is a design research consisting of three phases, namely the preliminary design, the design experiment, and the retrospective analysis. However, this study only shows the results in the design experiment phase, in particular on a pilot experiment. Data collection was done through several techniques, namely: video recordings, photograph, students work result, and students interview during learning. Student learning activities consist of four activities, namely observing the Lawang Sewu video, identifying two similar shapes, identifying the requirements of two similar shapes, and solving a contextual problem related to similarity. The results of this study indicate that through a series of activities that have been designed could help to stimulate students understanding of similarity concept by using Lawang Sewu context.
\end{abstract}

Key words: Similarity, Design Research, PMRI, Lawang Sewu Context

\section{Introduction}

Mathematics has an important role in our daily life. In addition, Mathematics is a science that has many parts with an unlimited span and depth (Ilgar, 2013). One of the important learning areas in mathematics and also the oldest branches in mathematics is geometry (Fidan, 2010). Based on the distribution of education standards for junior high school, geometry material has a large portion (41\%) compared to other materials such as algebra (29\%), numbers $(18 \%)$, and statistics and probability (12\%) (Putra, 2013). Within the knowledge of mathematics, the things learned in geometry are shapes and space (Senechal, 1990). In line with this, Reference (Sahin, 2008) stated that by mastering geometric thinking skills, students will be able to have an ability of problemsolving, critical thinking, and a better understanding of the other subjects in mathematics. Reference (Ruseffendi, 1991) asserted that one of beneficial in learning geometry is to developing logical thinking skill and making true generalization ability. Moreover, the students who acquire the ability and habit of problem solving in school tend to be individuals who can solve the problems in the social life in their future (Sahin, 2007; Turgut, 2007).

On the other hand, the ability of students in learning geometry is still low and need to be improved (Abdussakir, 2009). The lack of the students to solve the similarity are 1. Students difficult to determine two similarities or more 2. Students are able to solve similarity through the correct way but the result incorrect. 3. Students are able to solve the question and get a good result but incorrect way (Nafiin, 2018). The difficulty of students in understanding the material shown by students is still weak in understanding the concepts and principles of geometry. Difficulties can be changed by several factors including internal factors (from within students) and external factors (external environment of students). One of the external factors that influence student difficulties is teacher-centered learning (teacher center). Learning that complies with the teacher planning the difficulty of learning goals will reach. The purpose of mathematics learning itself is the learning process that focuses on children to apply it. This is consistent with (Kemendikbud, 2016) composing on the modern pedagogical dimension of learning, namely using a scientific (scientific) approach.

To overcome this problem one of the approaches that can be used in the learning process of mathematics is Indonesian Realistic Mathematics Education (PMRI) by using the right context. An effective PMRI approach to improve understanding of mathematical concepts because the PMRI approach is a 
process that constructs knowledge. This is in accordance with the result of some studies (Nursyahidah, 2014; Prahmana, 2012; Nursyahidah, 2018; Saputro, 2015) stated that PMRI approach involved in learning that is more concerned with student activities in the learning process in the classroom. Students are able to build their own knowledge of the problems that exist in mathematics.

There are several contexts used in PMRI research, for instance, traditional games (Nursyahidah, 2013; Prahmana, 2012), folklore, legend (Widyawati, 2016). In this study, the context to support the PMRI approach is Lawang Sewu which is a historical building in Central Java. The Lawang Sewu context is chosen because not only it has already familiar to students in Semarang but also it can represent similarity of two-dimensional shapes. The shape of the components of that building like doors, windows, pictures, and park as a model that allows representing some two-dimensional shape that similar.

To implement the study, the authors used design research method. It consists of three phases, namely: preliminary design, experiment (a pilot experiment and teaching experiment), and retrospectively analyze. But this current study was limited to the pilot phase of the experiment. From the above discussion, the researchers conduct a research with the aim of developing a theory of learning to assist students to understand the concept of the similarity using Lawang Sewu context.

\section{Methods}

The method used in this study is a design research which was designing learning similarity material for the third-grade students. The subject of this study was 6 students of ninth grade students of SMP Negeri 37 Semarang. This research was conducted in the second semester of academic year 2017/2018.

Design research is a method aiming to develop the Local Instructional Theory (LIT) to improve the quality (Bakker, 2003). In this study, the developed design was Hypothetical Learning Trajectory (HLT) which contained a series of students' learning activities. According to (Gravenmeijer, $\mathrm{K} \&$ Cobb, P. 2006) instructional design is done in this study consisted of three phases, namely:

a. Preliminary Design

The main objective at this stage is to develop a sequence of learning activities and designing instruments to evaluate the learning process

At this stage HLT designed containing anticipate things that might happen. Before designing, the researchers set learning goals or targets will be achieved and the starting point of learning. Some things you do at this stage is: (1) review the literature regarding the material similarity to the curriculum in 2013 revised edition, 2017, (2) designing the HLT to the context lawang sewu as the basis of its alleged strategy of beginning students, (3) designing an interactive video that will is used as a medium for learning, and (4) discuss with professors, teachers, and research experts.

\section{b. Design Experiment}

In this second phase, the researchers tested the design as found in the first phase of activities. The trial is aimed at exploring and guessing strategy and thinking students during the process of the true learning. Stage trial design is divided into two phases, namely that the pilot experiment and teaching experiment.

The pilot phase of this experiment also referred to as a bridge between the early phase of learning the experimental stage. The purpose of this experiment was to test initial HLT. The research will be made up of several things: a pilot experiment, which tested the HLT has been designed in a small group that involves high ability students, medium, and low respectively 2 children. Furthermore, researchers did Teaching experiment, which tested the HLT that has been designed, tested on a small group, and fixed in the actual class that is the subject of research, observation; and perform tests.

c. Retrospective analysis

Some of the steps to be taken at this stage include: (1) analyzing the data have been obtained from the stage of teaching, experiments, and the results of the analysis are used to plan activities and develop a plan of activities in the next learning, (2) comparing the HLT with students learning in the real, the results are used to answer the problem formulation. The goal is to develop a theory of local instruments. The techniques of collecting data to answer the research problems through observation, interview, and documentation.

The purpose of the observation is to get the idea of dealing with the social norms that apply 
mathematics in the classroom, the teaching methods used, class organization, the rules of the classroom, the students' work and the allocation of time during the learning process.

Interviews were conducted with mathematics education experts, teachers and students. Interview experts aim to determine the suitability of content and relevance, the application context, interoperability, and ease of material. The language is easy to understand and the adequacy of the time. The goal is to get indepth information about the difficulties of teachers in teaching materials, the level of understanding of students, teachers experience towards PMRI approach and experience of students toward PMRI approach. The role of researchers in the learning activities are for students ask some additional questions, observe learning activities, coordinate activities and make the changes necessary activities to provide relevant information about the research.

Documentation was carried out together with the observation to see how the learning process takes place, students strategies and thought processes of students from informal stages to formal stages in mathematics.

Data analysis techniques implemented qualitatively. The data have been collected in the initial experiments, pilot, and teach the experimental phase were analyzed on a retrospective analysis phase. The results of the analysis of observation sheets, interview results and the results of the pre-test phase of the pilot trial used as a guideline for designing the initial HLT. In addition to analyzing the written test results of students, analysis of data on study design methods by comparing the observations during the learning process with HLT designed.

\section{Results and Discussion}

At this stage, researchers examined the instrument that will be used for research. Researchers designed the learning trajectory, the implementation plan lessons, teacher guides, student activity sheets, and scoring guidelines. Learning activity undertaken can be seen as follows.

\subsection{Activity 1: Watching Video of Lawang Sewu}

Activity 1 contains about introducing Lawang Sewu as context for finding the concept of similarity. By using context Lawang Sewu, students are expected to find a common two or more forms. At the beginning of the lesson, the teacher gave apperception by asking, "Is there any one of you who have been there?", "Do you think any other forms of two-dimensional shape in Lawang Sewu?" This activity makes students answer the problem with vigor and high enthusiasm,

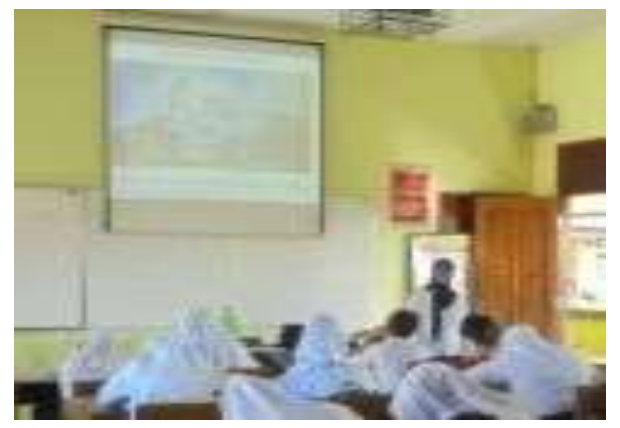

Figure 1. Students watched video of Lawang Sewu

The teacher then asks the students to work with a group activity sheet 1 . Students discussed together with the group of the activity sheet. In this phase, the teacher acts as a facilitator to observe the activities of the students in working groups. The problem that is issued in activity 1 is that students are used to watching Lawang Sewu videos and looking for objects of the same shape and if they are enlarged or reduced in the same scale. After completion of work, they presented the answer. From the answers presented, the students' understanding of the similarities began to be built. Students are able to conclude that two planes if enlarged or reduced scale will form a plane that congruent. The results of students' work in a group can be seen in the figure 2 .

In figure 2, students are asked to identify the existing image whether the size is the same or not. Furthermore, to find out more clearly an interview with students was conducted. The results of interviews with students can be concluded that students can identify the image the same size. From the written results and interviews it was proven that the purpose of this activity was achieved.

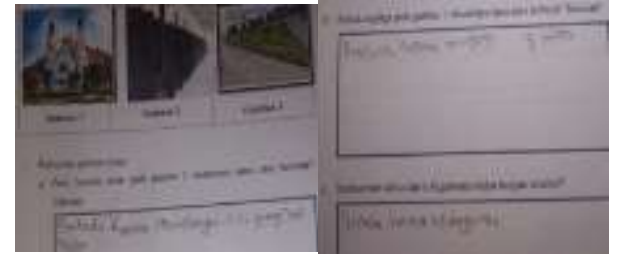

Figure 2. The students' answers on $1^{\text {st }}$ activity 


\subsection{Activity 2: Identify Two Forms of the Same}

In the second activity, students are asked to find two forms the same contained in Lawang Sewu. In this activity, students are asked to measure the image that has been provided by using a ruler to find the same picture or not. Furthermore, students are asked to compare the third image. From this comparison, students can discover which picture is the same or not. Answer students can be seen in Fig. 3.

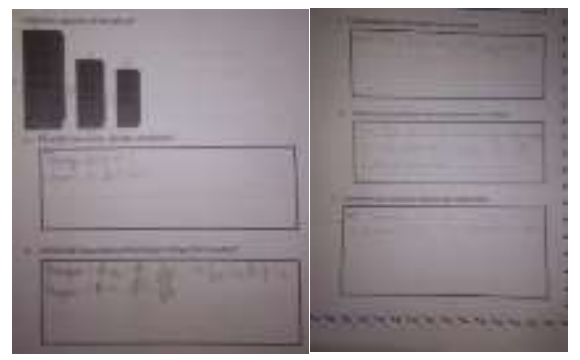

Figure 3. The students' answers on $2^{\text {nd }}$ activity

Based on Figure 3, with the help of images, students can identify two forms whether it is similar or not.

\subsection{Activity 3: Identifying Requirements of Two Similar Forms}

In the third activity, students were asked to identify the requirements of two similar forms contained in Lawang Sewu. In this activity, students were asked to compare the sides and corresponding angles of the image that has been provided by using a ruler to find the requisite the similar two forms. From the comparison of corresponding sides and angles, students can find the prerequisite of two similar forms. Answer students can be seen in Figure 4.

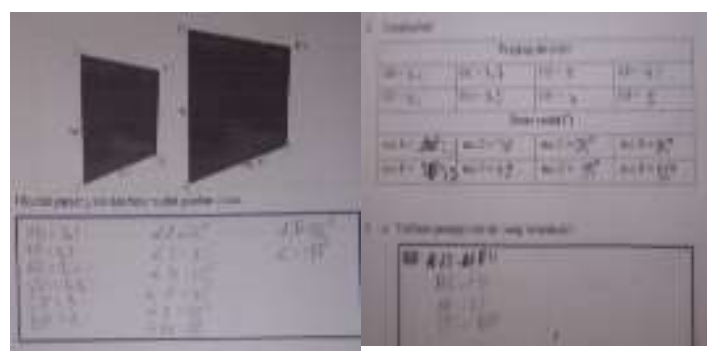

Figure 4. The students' answers on $3^{\text {rd }}$ activity
In Figure 4, students are correct in identifying the similar two-dimensional shapes. They solve the problem by comparing the corresponding sides and angles. Student answers are in line with the learning trajectory that has been designed.

\subsection{Activity 4: Solving Contextual Problems related to Similarity}

In this activity students were asked to solve contextual problems related to the similarity of two-dimensional shapes. Students were able to resolve the problem with the concept learned in previous material. In addition, the results of the students' answer is shown in Figure 5.

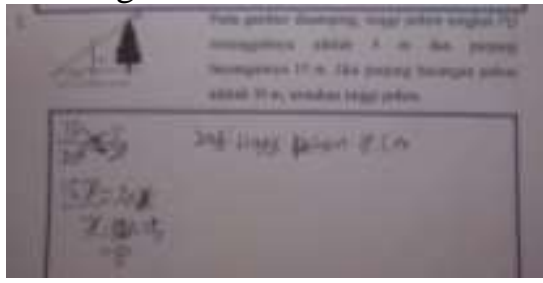

Figure 5. The students' answers on $4^{\text {th }}$ activity

Figure 5 shows that the students are already familiar with the concept of similarity so they can solve the contextual problems given related to similarity.

The PMRI approach is very well applied in mathematics learning because by using this approach students are asked to find their own concept of similarity material with the help of contextual problems surrounding the students. It is in line with the several studies (Nursyahidah, 2013; Nursyahidah, 2014; Nursyahidah, 2018; Nursyahidah, 2018; Widyawati, 2016) asserted that using PMRI approach in learning process by using appropriate context can help students understanding the concept learned. With the help of the context of Lawang Sewu which is a historical building where students are familiar with which is packaged in an interactive video so students are enthusiastic and more active in learning process that is why they can understand the concept learned deeply.

\section{Conclusion}

The hypothetical learning trajectory resulted in this study consist of four activities, namely watching the Lawang Sewu video, identifying two similar shapes, identifying the requirements of two similar 
shapes, and solving a contextual problem related to similarity. The results of this study indicate that through a series of activities that have been designed could help to stimulate students understanding of similarity concept by using Lawang Sewu context.

\section{References}

Abdussakir. (2009). Pembelajaran Geometri dan Teori Van Hiele. [Online]. Tersedia: http://abdussakir.wordpress.com/2009/01/ 25/ [21 Februari 2011].

Bakker, A. (2003). Design Research on How IT May Support The Development of Symbols and Meaning in Mathematics Education. Freudenthal Institute, Utrecht University, Netherlands.

Cobb, P., Stephan, M., McClain, K., \& Gravemeijer, K. (2001). Participating in Classroom Mathematical Practices. The Journal of the Learning Sciences. 10 (1\&2), 113-163

Cobb, Confrey, J., Sessa, A., Lehrer, R., \& Schauble, L. (2003). Design Experiments in Educational Research. Educational Researcher. 32(1),9-13

Fidan, Y., \& Türnüklü, E. (2010). Examination of 5th-grade students' levels of geometric thinking in terms of some variables. Pamukkale University Journal of Education, 27, 185-197.

Gravenmeijer, K \& Cobb, P. (2006). Design Research From A Learning Design Perspective. Educational Design Research. $17-55$.

Ilgar, L., \& Gülten, D. Ç. (2013). Matematik konularinin günlük yasamda kullaniminin ögrencilere ögretilmesinin gerekliligi ve önemi. Istanbul Zaim Üniversitesi Sosyal Bilimler Dergisi, Güz.

Kemendikbud. (2016). Lampiran Permendikbud Nomor 24 Tahun 2016 Tentang Standar Kompetensi Isi dan Kompetensi Dasar Pendidikan Dasar dan Menengah. Jakarta: Kemendikbud.

Nafiin, M., W., \& Budiarto, M., T. (2018). Analisis Kesalahan Peserta Didik dalam Menyelesaikan Soal Kesebangunan. MATHEdunesa. Surabaya: Universitas Negeri Surabaya

Nursyahidah, F., Ilma, R., \& Somakim. (2013). Supporting First Grade Student's Understanding of Addition up to 20 Using Traditional Game. IndoMSJME, Vol.4, No.2. $212-223$.
Nursyahidah, F., Ilma, R., \& Somakim. (2014). Instructional Design of Subtraction Using PMRI Approach Based on Traditional Game. SEA-DR. Palembang: Universitas Sriwijaya.

Nursyahidah, F., Saputro, B. A., \& Rubowo, M. R. (2018). Supporting Second Grade Lower Secondary School Students' Understanding of Linear Equation System in Two Variables Using Ethnomathematics. IOP Conf. Ser.: Inter. Cof. On Math., Sci, and Edu, 983012119.

Nursyahidah, F., Saputro, B. A., \& Rubowo, M. R. (2018). A Secondary Student's Problem Solving Ability in Learning Based on Realistic Mathematics with Ethnomathematics. JRAMathEdu. Semarang: Universitas PGRI Semarang.

Putra, H. D. (2013). Pembelajaran Geometri Dengan Pendekatan Savi Berbantuan Wingeom Untuk Meningkatkankemampuan Generalisasi Matematis Siswa SMP. Bandung: STKIP Siliwangi.

Ruseffendi, E. T. (1991). Pengantar Kepada Membantu Guru Mengembangkan Kompetensinya dan Pengajaran Matematika Untuk Meningkatkan CBSA. Bandung: Tarsito.

Sahin, O. (2008). In- \& pre-service elementary school teachers? Van Hiele reasoning stages. Master Thesis. Kocatepe University, Institute of Social Sciences, Afyon

Sahin, A. A. (2007). Determining the problem-solving strategies for the students aged 13-14 years. Master Thesis. Balikesir University, Institute of Natural Sciences, Balikesir.

Saputro, B. A., Prayito, M., \& Nursyahidah, F. (2015). Media Pembelajaran Geometri Menggunakan Pendekatan Pendidikan Matematika Realistik Berbasis GeoGebra. Kreano, 6(1), p. 33-38

Senechal, M. (1990). Shape. In L.A. Steen (ed.), On the Shoulders of Giants; New Approaches to Numeracy (pp. 139-182). Washington DC: National Research Council.

Turgut, U.M., \& Yilmaz, S. (2007). Geometri derslerine nasil giris yapardik? Ilkögretim matematik ögretmen adaylarinin görüsleri. Bilim Egitim ve Düsünce Dergisi, 7(4).

Widjaja, W. (2008). Local Instruction Theory 
on Decimals: The Case of Indonesian Preservice Teachers. Disertasi. Melbourne Graduate school of Education, The University of Melbourne, Melbourne.

Widyawati, W., Ilma, R., \& Somakim.
(2016). Desain Pembelajaran Sudut Menggunakan Konteks Rumah Limas di Kelas VII. JINop. Vol.2, No.2. Palembang. 